\title{
Plany eksperymentu.
}

\section{Opracowanie planu oceny czułości badań magnetyczno-proszkowych}

\section{Plans for the experiment. Develop of a plan to evaluate the sensitivity of magnetic-powder testing}

\section{Streszczenie}

W artykule podjęto tematykę związaną z procesem planowania eksperymentu. Przedstawiono poszczególne etapy planowania, z zastosowaniem metod analizy, oraz wybrane metody planowania badań doświadczalnych. $\mathrm{Na}$ podstawie opisanych zagadnień w pierwszej części opracowania dobrano odpowiednią metodykę oraz utworzono plan do badań magnetyczno-proszkowych.

\section{Wstęp}

Planowanie eksperymentu pozwala na dokładne określenie zamierzonych celów oraz czynności prowadzących do ich osiągnięcia.

Problemy przedstawione w artykule bardzo często pojawiają się w czasie planowania badań, czy też opracowywaniu prac doktorskich. Ponieważ spawalnictwo jest szczególną dziedziną, a otrzymywane wyniki nie są w pełni przewidywalne, podjęto próbę opisania planu eksperymentu w odniesieniu do badań magnetycznoproszkowych, które odgrywają duże znaczenie w procesie kontroli złączy spawanych. Oznacza to nie tylko badania podstawowe, czy opis praktycznych przypadków, ale również badania eksperymentalne, wymagające opracowania planu eksperymentu. Mam nadzieję, że ten artykuł pomoże młodym naukowcom i doktorantom.

\section{Pojęcia podstawowe}

Planowanie jest określane jako element metodologii zarządzania, mający na celu podjęcie i zainicjowanie działań, które pozwolą na wywołanie

Mgr inż. Karolina Poch - Politechnika Częstochowska.

\section{Abstract}

In this study addresses issues related to the planning process of the experiment. Presents the various stages of planning, the methods of analysis and some methods of experimental planning. Based on the issues described in the first part of the study were chosen appropriate methodology, and created a plan to study magnetic - powder testing.

określonych skutków (wyników) niemogących wystąpić samoistnie. Planowanie jest nieodłącznym elementem, każdego procesu decyzyjnego, gdyż pozwala na dokładne określenie cech badanego elementu, wartości wejściowych i wyjściowych do obiektu badań, a także najbardziej efektywnych procedur badawczych, umożliwiających otrzymanie spodziewanych wyników.

Eksperyment jest określany jako proces badawczy jakiegoś zjawiska, w wyniku którego gromadzi się informacje (dane) umożliwiające zdefiniowanie jego modelu np. określenie cech fizycznych itp.. Wyróżnia się różne rodzaje modeli, jednak najczęściej stosowany jest model matematyczny [1].

Zarówno planowanie, jak i przeprowadzanie eksperymentu składa się na teorię eksperymentu. Obejmuje ona:

- planowanie eksperymentów,

- metodykę modelowania matematycznego,

- technikę pomiarów,

- analizę wyników pomiaru.

W tym opracowaniu podjęta została tematyka związana z zagadnieniem planowania eksperymentu. Metodyce modelowania matematycznego zostanie poświęcone odrębne opracowanie.

Teoria eksperymentu narodziła się wraz rozwojem nauki, i ma zastosowanie gdy:

- liczba kombinacji wartości czynników badanych przekracza praktyczne możliwości realizacji doświadczeń, 
- nie wszystkie czynniki moga być badane oddzielnie, ponieważ niektóre z nich są współzależne (od czynników dotychczas nieuwzględnianych w realizowanym doświadczeniu),

- istnieją czynniki, których wartości nie można ustalić na stałym poziomie.

Powstały wówczas plany badań doświadczalnych, które pozwoliły na zwiększenie ilości oraz jakości uzyskiwanych informacji na temat badanego zjawiska oraz zmniejszenie liczby koniecznych pomiarów, zmniejszenia kosztów i czasu trwania procesu badawczego. Ponadto w planach badań doświadczalnych uwzględniono zasadę, aby liczba pomiarów była jak najmniejsza.

Stosując te zasady teorii eksperymentu, ustala się wstępnie cel oraz metodę analizy wyników pomiaru oraz określa się punkty pomiarowe, które otrzymuje się na podstawie określonych procedur matematycznych. Pojedynczy punkt pomiarowy, będący s-wymiarowym wektorem wartości wielkości wyjściowych, nazywany jest układem planu eksperymentu, natomiast zbiór wszystkich punktów stanowi plan eksperymentu.

Rozmieszczenie i charakter wyznaczanych punktów pomiarowych zależy od celu badań oraz wykorzystanej metody analizy matematycznej pozwala na:

- podkreślenie poszukiwanych cech obiektu, np. liniowości, współzależności zmiennych wejściowych, niezależności wielkości wyjściowej od wielkości wejściowych,

- wyznaczenie ekstremum globalnego funkcji i obiektu badań,

- zmniejszenie nakładu obliczeniowego przy identyfikacji modelu obiektu [5].

\section{Planowanie eksperymentu}

Planowanie eksperymentów prowadzi się w celu wyznaczenia bądź weryfikacji podanego opisu matematycznego modelu obiektu, hipotez badawczych, obserwacji nowych zjawisk oraz ułatwienia obliczeń w fazie opracowywania wyników.

Proces planowania może mieć różny przebieg, ze względu na przedmiot badań, wybrane procedury, a także techniki badawcze. Pomimo tego, że każdy proces planowania jest inny to istnieją pewne ogólne reguły postępowania w procesie planowania, stosowane bez względu na rodzaj i charakter przeprowadzanego badania. Zastosowanie się do ogólnie przyjętych zasad tworzenia planu eksperymentu, wprowadza porządek do procesu planowania [1].

Istota przydatności teorii eksperymentu w planowaniu wynika z właściwie dobranego programu badań, który zapewnia:

- wyznaczenie funkcji stanowiącej matematyczny opis obiektu badań, tzw. modelu OB - jest to funkcja o z góry przyjętej postaci,

- ograniczenie ogólnej liczby pomiarów do rozsądnych, raczej małych wartości.
Realizacja tak formułowanych zadań jest możliwa z wykorzystaniem odpowiednio dobranych i opracowanych adekwatnie do rodzaju badania planów:

- jeżeli celem badań jest wyznaczenie funkcji obiektu badań, to należy poszukiwać planów zaliczanych do grupy planów zdeterminowanych (uwarunkowanych);

- jeżeli celem badań jest weryfikacja istotności wpływu wielkości wejściowych, to należy poszukiwać planu należącego do grupy planów statycznych randomizowanych (losowych);

- jeżeli celem badań jest wyznaczenie ekstremum obiektu badań, to właściwe plany znajdują się w grupie planów optymalizacyjnych.

Ogólnie przyjęte zasady dotyczące planowania badań doświadczalnych składają się z opisanych poniżej etapów.

\section{Etap I - Charakterystyka obiektu badań (model OB)}

Pierwszy etap badań polega na wyznaczeniu zagadnienia wymagającego rozwiązania metodą doświadczalną, określeniu wielkości cechujących obiekt badań (wielkości wejściowe, wyjściowe, stałe i zakłócające) oraz ustaleniu relacji pomiędzy wielkościami, które należy rozpoznać w wyniku badań doświadczalnych [2].

Dzięki wprowadzeniu uniwersalnego modelu obiektu badań przedstawionego na rysunku 1 uzyskiwane są informacje, które opisują następujące wielkości:

- niezależne wielkości wejściowe: $x_{1}, x_{2}, \ldots, x_{k}, \ldots, x_{i}$, $\mathrm{k}=1,2, \ldots ;$ zalicza się do nich te, które mają wpływ na wielkości wyjściowe interesujące osobę przeprowadzającą badanie. Zazwyczaj są to wielkości: techniczne, fizyczne, chemiczne, ekonomiczne i inne, które są wzajemnie niezależne oraz mierzalne. Każdej wielkości wejściowej należy określić zakres:

$$
x_{k \min } \leq x_{k} \leq x_{k \max }, k=1,2, \ldots, i
$$

gdzie: i - liczba wielkości wejściowych [2];

- zależne wielkości wyjściowe: $\mathrm{y}_{1}, \mathrm{y}_{2}, \ldots, \mathrm{z}_{\mathrm{p}}, \ldots, \mathrm{z}_{\mathrm{w}}$, $z=1,2, \ldots, w$, które będą przedstawiać mierzalne następstwa działania obiektu;

- wielkości stałe c, które wpływają na działanie układu, ale ich wartości są znane i niezmienne w czasie, przez co mogą zostać pominięte w analizie statystycznej [2];

- wielkości zakłócające h, spowodowane czynnikami losowymi, które oddziałują na wielkości wyjściowe obiektu badań.

Określenie charakterystyki obiektu badań stanowi podstawę do wyznaczenia celu badań, uzyskanie informacji dotyczących zależności pomiędzy wielkościami wejściowymi a wielkościami wyjściowymi. Ustalenie wagi wpływu wielkości wejściowych na wyjściowe umożliwia pominięcie tych wielkości wejściowych, których wpływ okaże się nieistotny. 


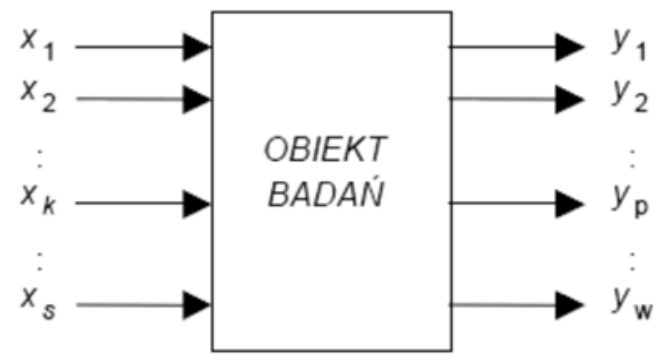

Rys. 1. Uniwersalny model obiektu badań [2]

Fig. 1. Universal model of the object of research [2]

\section{Etap II - Cel badań doświadczalnych}

Etap drugi jest współzależny do etapu pierwszego; są. W przypadku planowania eksperymentu wyróżnia się trzy ogólne cele:

- wyznaczenie stanu granicznego symptomów lub granic do klasyfikacji zdatności i niezdatności badanych obiektów,

- weryfikację istotności wpływu wybranych wielkości wejściowych na wielkości wyjściowe na tle zakłóceń losowych,

- wyznaczenie funkcji (modelu) obiektu badań, gdzie celem jest ustalenie związków pomiędzy wszystkimi wielkościami wejściowymi a wielkością wyjściową.

Wybór celu umożliwia uzyskanie informacji tylko z określonego charakterystycznego zakresu, dla poszczególnych zmiennych i właściwości. Biorąc pod uwagę cel pierwszy, otrzymuje się informację, dla których wielkości wejściowych wielkość wyjściowa osiąga ekstremum i ile ono wynosi.

Wybierając cel drugi, uzyskuje się informację, czy wielkości wejściowe mają wpływ na wielkość wyjściową w środowisku zakłóceń losowych. Jeżeli obiekt badań jest bardzo złożony, wykonuje się serie badań eliminacyjnych, mających na celu wykluczenie tych wielkości wejściowych, które mają nieznaczący wpływ na zmianę wielkości wyjściowej.

Ostatnią możliwą opcją jest wybór celu opisującego wyznaczenie funkcji OB. Wówczas otrzymuje się pełną informację na temat obiektu badań. Na podstawie przeprowadzonego doświadczenia, uzyskuje się poszczególne wartości współczynników funkcji, która opisuje reakcję badanego obiektu na zmiany zachodzące w przyjętych zakresach.

\section{Etap III - Metoda badań doświadczalnych}

Kolejny etap planowania eksperymentu polega na wyborze odpowiedniego planu działania, a także określeniu sposobu jego wykonania, w ilu seriach pomiarowych, z użyciem jakich środków pomiarowych. Klasyfikacja planów doświadczeń została przedstawiona na rysunku 2.

Plan doświadczeń dobiera się odpowiednio do celu badania. Jeśli celem badań jest wyznaczenie stanu

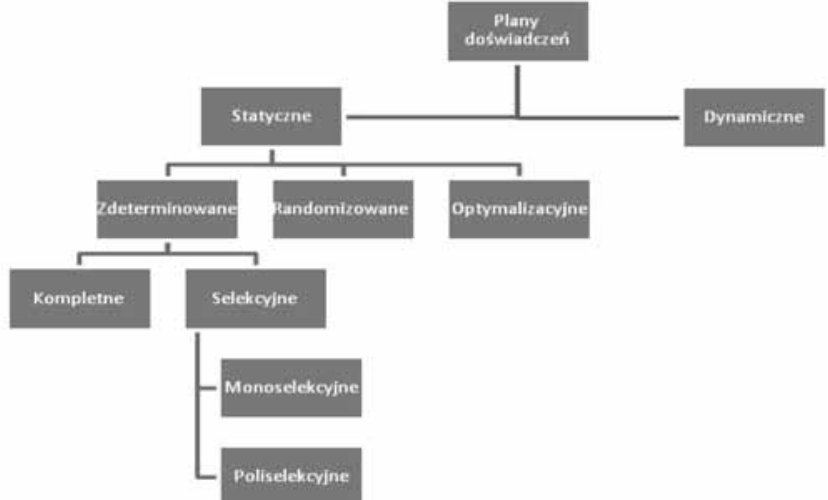

Rys. 2. Klasyfikacja planów doświadczeń [2]

Fig. 2. Experience rating plans [2]

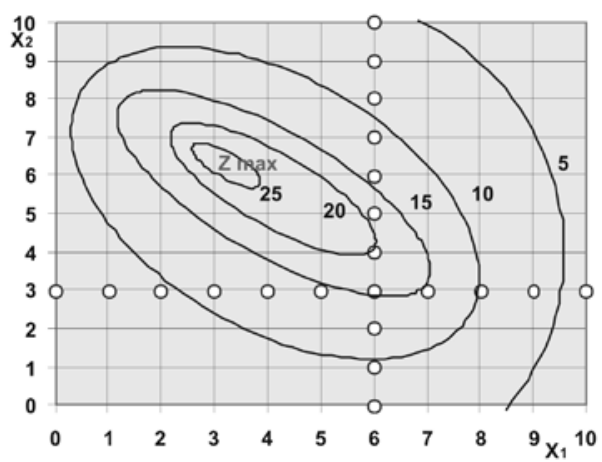

Rys. 3. Przykładowy plan tradycyjny

Fig. 3. Traditional plan sample

granicznego symptomów lub granic dla klasyfikacji zdatności i niezdatności badanych obiektów, plan należy dobrać z grupy planów statycznych optymalizacyjnych.

Chcąc zweryfikować istotność wpływu wybranych wielkości wejściowych na wielkości wyjściowe na tle zakłóceń losowych, należy wybrać plan z grupy statycznych randomizowanych.

Stawiając za zadanie wyznaczenie funkcji (modelu) obiektu badań, gdzie celem jest ustalenie związków pomiędzy wszystkimi wielkościami wejściowymi a wielkością wyjściową, należy posłużyć się planem z grupy zdeterminowanych. Na rysunku 3 przedstawiono przykładowy plan badań.

\section{Etap IV - Realizacja badań doświadczalnych}

Po dokonaniu wyboru planu realizacji eksperymentu należy przystąpić do pomiarów oraz badań.

Pomiary wartości badanych wielkości charakterystycznych realizuje się według przyjętego sposobu z określoną liczbą powtórzeń.

Na tym etapie należy zwrócić szczególną uwagę na uniknięcie wystąpienia błędów systematycznych. Kolejność realizacji pomiarów nie musi być zgodna z kolejnością układów w planie doświadczenia, lecz może być losowa. Można wykorzystać np. tablice liczb losowych w celu uzyskania losowej kolejności realizacji pomiarów. 


\section{Etap V - Analiza wyników pomiaru}

Model obiektu badań przedstawia się w postaci zależności matematycznej nazywanej funkcją modelu, opisującej związek między wielkościami wejściowymi $x$, a wielkością wyjściową modelu y:

$$
\check{y}=f(a ; x)
$$

gdzie

$$
a=\left[a_{1}, a_{2}, \ldots, a_{p}\right]^{\top}
$$

jest wektorem $\mathrm{P}$ parametrów.

Istotne jest ustalenie struktury modelu, a więc odpowiedni wybór jego funkcji. Przy złym wyborze nie uzyska się dostatecznego dopasowania wyników pomiarów do wartości wyjściowych modelu dla punktów pomiarowych niewchodzących w skład planu doświadczenia. Przyjęty model nie będzie wówczas adekwatny do obiektu badań i uniemożliwi przewidywanie przebiegu zjawiska lub zachowania obiektu w różnych warunkach. Najczęściej stosowaną funkcją modelu jest liniowa kombinacja funkcji bazowych:

$$
\check{y}=a_{0} f_{0}(x)+a_{1} f_{1}(x)+\cdots+a_{p} f_{p}(x)
$$

którą można zapisać w postaci wektorowej:

$$
\check{y}=|f(x)| a
$$

gdzie: $f(x)=\left[f_{0}(x), f_{1}(x), \ldots, f_{p}(x)\right]$ jest wektorem funkcji bazowych.

Jeżeli liczba pomiarów $\mathrm{n}$ wykonywanych $\mathrm{w}$ czasie eksperymentu jest równa liczbie parametrów $P$ (plan nasycony), to identyfikacja parametryczna modelu opisanego funkcją (2) polega na rozwiązaniu układu $\mathrm{P}$ równań.

Jeżeli liczba pomiarów $n$ jest większa od liczby parametrów $\mathrm{P}$ (plan nienasycony), to identyfikację parametryczną przeprowadza się metodą regresji polegającą na znalezieniu takich wartości parametrów $a_{1}, a_{2}, \ldots, a_{p}$, dla których funkcja modelu aproksymuje, najlepiej w sensie przyjętego kryterium, wyniki pomiarów y dla ustalonego planu doświadczenia $\mathbf{X}$. Najbardziej rozpowszechnioną metodą aproksymacji jest metoda najmniejszych kwadratów. W metodzie tej funkcjonałem podlegającym minimalizacji jest suma kwadratów błędów aproksymacji:

$\breve{y}=a_{0}+a_{1} x_{1}+\cdots+a_{i} x_{i}+a_{11} x_{1}^{2}+\cdots+a_{i i} a_{i}^{2}+a_{12} x_{1} x_{2}$

gdzie: y̌ jest wektorem kolumnowym wyjść modelu obliczonym ze wzoru (2), a sumowanie wykonuje się względem pomiaru $\mathrm{u}=1,2, \ldots, \mathrm{n}$.

Dominującą postacią funkcji aproksymującej utworzonej na podstawie modelu liniowego względem funkcjibazyjestwielomianalgebraicznydrugiegostopnia z podwójnymi iloczynami stanowiącymi tzw. interakcje, o ogólnej postaci:

$$
S=\Sigma[\Delta(u)]^{2}=\Sigma[\check{y}(u)-y(u)]=(\check{y}-y)^{\tau}(\breve{y}-y)=\varphi(a)
$$

Przykładowo dla dwóch zmiennych wejściowych $\mathrm{x}_{1}$ i $x_{2}$ wielomian drugiego stopnia jest następujący:

$$
\check{y}=a_{0}+a_{1} x_{1}+a_{2} x_{2}+a_{12} x_{1} x_{2}+a_{11} x_{1}^{2}+a_{22} x_{2}^{2}
$$

$\mathrm{Na}$ podstawie zdefiniowanych funkcji bazowych i macierzy $\mathbf{X}$ tworzona jest macierz $\mathbf{F}$ o wymiarze $\mathrm{n} \times \mathrm{N}_{\mathrm{b}}$, która pełni rolę macierzy obserwacji nowych zmiennych wejściowych. Liczba tych zmiennych jest taka sama jak liczba identyfikowanych parametrów $\mathrm{N}_{\mathrm{b}}$.

Tworzenie macierzy $\mathbf{F}$ polega na wykonaniu na określonych argumentach macierzy $\mathbf{X}$ operacji określonych przez poszczególne funkcje bazowe. Dla wielomianu drugiego stopnia macierz $\mathbf{F}$ ma postać:

$$
\mathbf{F}=\left[\begin{array}{cccccc}
1, & x_{11}, & x_{12}, & x_{11} x_{12}, & x_{11}{ }^{2}, & x_{12}{ }^{2} \\
1, & x_{21}, & x_{22}, & x_{21} x_{22}, & x_{21}{ }^{2}, & x_{22}{ }^{2} \\
1, & \ldots, & \ldots, & \ldots, & \ldots, & \ldots \\
1, & x_{u 1}, & x_{u 2}, & x_{u 1} x_{u 2}, & x_{u 1}{ }^{2}, & x_{u 2}{ }^{2} \\
1, & \ldots, & \ldots, & \ldots, & \ldots, & \ldots \\
1, & x_{n 1}, & x_{n 2}, & x_{n 1} x_{n 2}, & x_{n 1}^{2}, & x_{n 2}{ }^{2}
\end{array}\right]
$$

Identyfikacja parametryczna modelu dla planu nasyconego sprowadza się do rozwiązania układu równań

$$
\mathrm{Fa}=\mathrm{y}
$$

Dla planu nienasyconego układ ten jest sprzeczny ze względu na błędy pomiarów wielkości wyjściowej y i/lub nieodpowiedni dobór struktury modelu. Wtedy, wykorzystując warunek minimalizacji funkcjonału danego wzorem (6), rozwiązuje się tzw. równania normalne określone wzorem:

$$
\mathrm{F}^{\top} \mathrm{Fa}=\mathrm{F}^{\mathrm{\top}} \mathrm{y}
$$

Jeżeli podczas wykonywania pomiarów przyjęto liczbę powtórzeń u-tego układu planu doświadczenia równą $r_{u}$, to równania normalne zapisuje się w postaci:

$$
\mathrm{F}^{\mathrm{T}} \mathrm{RFa}=\mathrm{F}^{\mathrm{T}} \mathrm{Ryy}
$$

gdzie: $\mathbf{R}$ jest macierzą diagonalną powtórzeń pomiarów o wymiarze $\mathrm{n} \times \mathrm{n}$ :

$$
R=\operatorname{diag}\left(r_{1}, r_{2}, \ldots, r_{n}\right)
$$

Wektor y̌ jest natomiast wektorem wartości średnich wielkości wyjściowej dla kolejnych układów 
planu doświadczenia:

$$
\begin{gathered}
\bar{y}=\left[\overline{y_{1}} \overline{y_{2}} \ldots \overline{y_{n}}\right]^{T} \\
\overline{y_{u}}=\frac{1}{r_{u}} \sum_{j=1}^{r_{u}} \overline{y_{u}^{(j)}}
\end{gathered}
$$

Rozwiązanie układu równań (10) wymaga w pierwszej kolejności wyznaczenia macierzy informacyjnej Fishera o postaci:

$$
M=F^{\top} R F
$$

Następnie oblicza się wyznacznik macierzy informacyjnej i sprawdza warunek:

$$
\operatorname{det}(M) \neq 0
$$

Jeżeli warunek ten nie jest spełniony, tzn. że macierz $\mathrm{M}$ jest osobliwa i należy zmodyfikować plan doświadczenia. $W$ przeciwnym razie oblicza się macierz odwrotna (kowariancyjną) $\mathbf{C}=\mathbf{M}^{-1}$ i rozwiązuje układ równań normalnych ze wzoru:

$$
a=C F^{T} R \bar{y}
$$

Metoda najmniejszych kwadratów rozwiązywania układu równań normalnych jest szczególnie przydatna do aproksymacji wyników pomiarów wielomianami liniowymi oraz wielomianami drugiego stopnia. Dla wielomianów wyższych rzędów moga wystapić trudności w ocenie zgodności funkcji modelu z zachowaniem się obiektu badań w pełnym zakresie wartości wejściowych.

\section{Etap VI - Wnioski z badań}

Po przeprowadzeniu analizy wyników pomiarów przystępuje się do analizy merytorycznej tj. sporządzenia opisu zaobserwowanych zjawisk. W ramach analizy merytorycznej, dokonuje się oceny poprawności realizacji badań oraz stosowanych metod analizy statystycznej.

Wnioski formułuje się w postaci:

- wniosków poznawczych, opisujących nowe poznane zjawiska, prawa itp.,

- wniosków utylitarnych (praktycznych), opisujących wdrożenia nowych konstrukcji, technologii,

- wniosków rozwojowych i określających zagadnienia wymagające dalszego rozpoznawania na drodze doświadczalnej.

\section{Wybrane metody planowania eksperymentu}

\section{Planowanie dwupoziomowe}

Metoda ta wykorzystywana jest do identyfikacji liniowych modeli obiektów. W metodzie tej każda
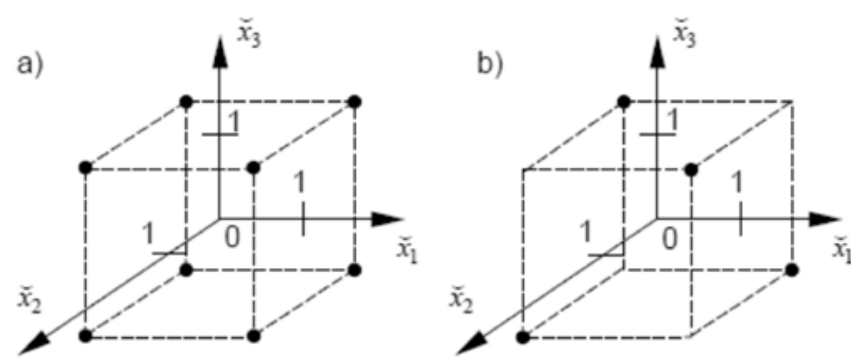

Rys. 4. Rozmieszczenie we współrzędnych unormowanych układów planu dwupoziomowego: a) całkowitego, b) ułamkowego [4]

Fig. 4. Coordinates the deployment of standardized systems two-tier plan total, b) fractional [4]

zmienna wejściowa przyjmuje tylko dwie wartości (poziomy). Łączna liczba układów planu eksperymentu w planie dwupoziomowym wynosi $2^{\mathrm{s}}$, gdzie $s$ jest liczbą zmiennych wejściowych. Taki plan nosi nazwę $d w u-$ poziomowego całkowitego lub kompletnego i oznaczany jest symbolem $2^{\mathrm{s}}$. Dla większej liczby zmiennych wejściowych przeprowadzenie eksperymentu całkowitego jest praktycznie niemożliwe ze względu na dużą liczbę koniecznych pomiarów. W takim przypadku stosowane są plany ułamkowe (oznaczane symbolem $2^{\mathrm{S}-\mathrm{P}}$ ), zawierające pewną liczbę układów z planu eksperymentu całkowitego. Istnieją zatem plany połówkowe, ćwiartkowe, ósemkowe itd. Unormowane zmienne wejściowe w planie dwupoziomowym przyjmują wartości $\check{x}_{\bar{x}}-\{-1,1\}$. Rozmieszczenie układów planu całkow tego i ułamkowego (połówkowego) dla trzech zmiennych wejściowych we współrzędnych unormowanych podano na rysunku 4.

Wybór układów nie może być przypadkowy, gdyż plan ułamkowy dla standaryzowanych zmiennych wejściowych powinien spełniać warunki:

- symetrii układów względem środka eksperymentu,

- ortogonalności, polegającej na zerowaniu wszystkich iloczynów skalarnych wektorów kolumnowych unormowanej macierzy $\mathbf{X}$,

- równości sum kwadratów we wszystkich kolumnach unormowanej macierzy $\mathbf{X}$ [5].

\section{Planowanie trójpoziomowe}

Metoda ta umożliwia identyfikację kwadratowego modelu obiektu, a unormowane zmienne wejściowe przyjmują wartości $\check{x} \check{x}_{k}=\{-1,0,1\}$. W planie trójpoziomowym całkowitym (oznaczenie $3^{\text {s}}$ ) występuje bardzo gwałtowny wzrost liczby układów wraz ze wzrostem liczby wejść obiektu, stąd ma bardzo małe możliwości praktyczne. Identyfikacja modelu na podstawie planu trójpoziomowego jest bardziej skomplikowana niż na podstawie planu dwupoziomowego. $Z$ tego powodu nie zostały opracowane plany eksperymentów trójpoziomowych ułamkowych [3]. 


\section{Planowanie wielopoziomowe}

Planowanie wielopoziomowe zapewnia identyfikację modeli liniowo-kwadratowych.

Przypadek planowania wielopoziomowego - planowanie pięciopoziomowe - stanowi rozszerzenie planowania dwupoziomowego i jest najczęściej wykorzystywane $w$ praktyce.

Wyróżnia się trzy zasadnicze typy planowania wielopoziomowego:

- planowanie kompozycyjne,

- planowanie ortogonalne,

- planowanie rotatabilne.

Planowanie kompozycyjne jest rozwinięciem planowania dwupoziomowego typu $2^{\mathrm{S}}$ lub $2^{\mathrm{s}-\mathrm{P}} \mathrm{o}$ dwa rodzaje układów (dla zmiennych unormowanych):

- gwiezdne typu $(0, \ldots, 0, \pm \alpha, 0, \ldots, 0)$, w których zmieniane są kolejno wartości zmiennych wejściowych między poziomami $\pm \alpha$ dla pozostałych zmiennych na poziomie 0 , przy czym wielkość $\alpha$ stanowi ramię gwiezdne planu,

- centralne typu $(0,0, \ldots, 0)$ stanowiące centrum planu eksperymentu.

Przykłady planów kompozycyjnych dla unormowanych zmiennych wejściowych przedstawiono na rysunku 5.

Liczba układów planu kompozycyjnego wynosi $\mathrm{n}=2 \mathrm{~S}+2 \mathrm{~s}+1$ (2S układów planu dwupoziomowego, $2 s$ układów gwiezdnych i jeden układ centralny). Stąd podstawową zaletą tego planu jest znaczne ograniczenie liczby układów w porównaniu z planem trójpoziomowym, w szczególności dla większych wartości s.

Dobierając odpowiednią wartość ramienia gwiezdnego a w planie kompozycyjnym oraz zwiększając do $\mathrm{n}_{\mathrm{o}}$ liczbę układów $\mathrm{w}$ centrum planu, można spełnić postulat ortogonalności planu doświadczenia. Uzyskujemy w ten sposób znaczne uproszczenie obliczeń przy wyznaczaniu parametrów modelu identyfikowanego obiektu oraz ocenie statystycznej otrzymanych współczynników. Plan spełniający postulat ortogonalności nazywany jest planem ortogonalnym.

Wartość ramienia gwiezdnego planu ortogonalnego dla określonych wartości s i $n_{0}$ wyznacza się ze wzoru:

$$
\alpha=\sqrt{\frac{1}{2}\left[\sqrt{n_{d}\left(n_{d}+2 S+n_{0}\right)}-n_{d}\right]}
$$

gdzie $n_{d}=2^{s}$ dla panu całkowitego lub $n_{d}=2^{s-p}$ dla planu ułamkowego.

Planowanie rotatabilne ma na celu spełnienie postulatu niezależności planu od obrotu układu współrzędnych w przestrzeni wielkości wejściowych. Zastosowanie planu rotatabilnego umożliwia identyfikację modelu o wariancjach zależnych tylko od odległości od punktu centralnego eksperymentu. Warunek rotatabilności planu jest spełniony, jeżeli wartość ramienia gwiezdnego wynosi $\alpha=\sqrt{4} 2^{S}$ dla panu całkowitego lub $\alpha=\sqrt[4]{2^{\text {S-P }}}$ dla planu ułamkowego.
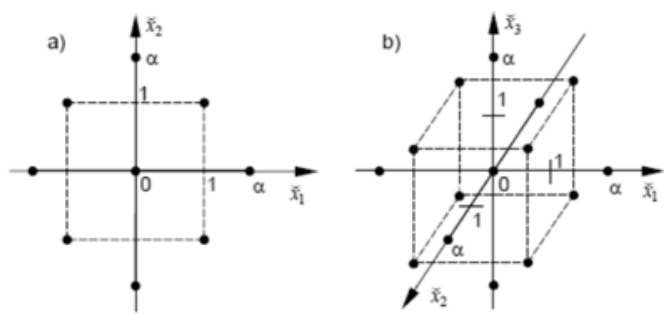

Rys. 5. Plany wielopoziomowe (kompozycyjne) we współrzędnych unormowanych dla różnej liczby zmiennych wejściowych: a) dwóch, b) trzech [4]

Fig. 5. Plans for a multi-level (compositional) in normalized coordinates for differenthe number of input variables: a) two, b) three [4]

Tablica I. Zestawienie optymalnych wartości i parametrów dla planu rotatabilnego

Table I. Summary of optimal values and parameters for the plan

\begin{tabular}{|c|c|c|c|c|c|}
\hline $\mathrm{s}$ & 2 & 3 & 4 & 5 & 6 \\
\hline $\mathrm{a}$ & 1,414 & 1,682 & 2,000 & 2,378 & 2,828 \\
\hline $\mathrm{n}_{0}$ & 5 & 6 & 7 & 10 & 15 \\
\hline $\mathrm{n}$ & 13 & 20 & 31 & 52 & 91 \\
\hline
\end{tabular}

W tablicy I podano zestawienie wartości ramienia gwiezdnego, zalecaną liczbę układów $w$ centrum planu $\mathrm{n}_{\circ}$ oraz łączną liczbę układów $\mathrm{n}$ planu rotatabilnego dla liczby zmiennych wejściowych od 2 do 6 [3].

\section{Planowanie sympleksowe}

W omawianych dotąd metodach planowania wartość wyjściową obiektu opisanego s-zmiennymi wejściowymi traktowano jako funkcję s zmiennych niezależnych aproksymowaną za pomocą wielomianu algebraicznego stopnia R. W metodzie planowania sympleksowego natomiast zmienne wejściowe związane są zależnością sumacyjną, która zmniejsza liczbę zmiennych niezależnych do s - 1. Do opisu obiektu, na który nałożone są ograniczenia, stosuje się wielomian zredukowany stopnia $R-1$, który uzyskuje się drogą odpowiednich przekształceń wielomianu algebraicznego stopnia R. Często zachodzi potrzeba ograniczenia dużej liczby współczynników wielomianów zredukowanych. Usuwając część z nich, uzyskuje się uproszczone wielomiany zredukowane [3].

Sympleksowy plan eksperymentu może zawierać wyłącznie układy stanowiące punkty leżące na sympleksie s-wymiarowym. Do wyznaczenia K współczynników wielomianu zredukowanego stopnia $\mathrm{R}$ dla $\mathrm{s}$ zmiennych stosowane są plany siatkowe całkowite typu $\{\mathrm{s}, \mathrm{R}\}$. Plan siatkowy całkowity $\{\mathrm{s}, \mathrm{R}\}$ jest zbiorem układów określonych wzorami:

oraz

$$
x_{k}=0, \frac{1}{R}, \frac{2}{R} \ldots \frac{R}{R}
$$

$$
\sum_{k-1}^{s} x_{k}=1
$$

Przykładowe plany typu $\{3 . R\}$ przedstawiono na rysunku 6. 

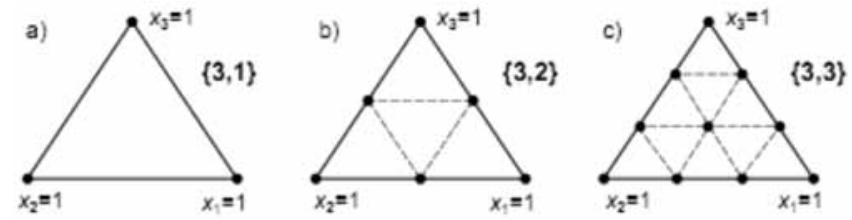

Rys. 6. Całkowity plan sympleksowy dla trzech zmiennych stopnia: a) pierwszego, b) drugiego, c) trzeciego [4]

Fig. 6. The overall sympleks plan for the three variables degree: a) first, b) second, c) third [4]

\section{Przykład planu eksperymentu badań magnetyczno-proszkowych złączy spawanych}

$\mathrm{Na}$ podstawie własnych badań i wstępnych wyników opracowano następującą koncepcję stworzenia planu eksperymentu badawczego.

Przed przystąpieniem do wykonania badań magnetyczno-proszkowych sporządzono diagram blokowy procesu. Ma on na celu przedstawienie relacji pomiędzy wykonywanymi czynnościami i zmiennymi, od których mogą zależeć otrzymane wyniki. Diagram ten pozwoli na jednoznaczne określenie, który z czynników ma znaczący wpływ na zmienność wartości otrzymywanych wyników. Plany, o których mowa, zakładają badanie efektów wzajemnych oddziaływań poszczególnych czynników procesu, występujących na różnych poziomach wartości. Eksperyment jest realizowany przez

\begin{tabular}{|c|c|c|c|}
\hline & \multicolumn{2}{|c|}{$\begin{array}{c}\text { Badanie magnetyczno - proszkowe } \\
\text { płyty próbnej }\end{array}$} & \\
\hline Zmienne niezależne & Operacje jednostkowe & & Zmienne zależne \\
\hline Rodzaj materiału, wymiary & \multirow{2}{*}{$\begin{array}{l}\text { Demagnetyzacja wstępna } \\
\text { Przygotowanie powierzchni } \\
\text { do badań }\end{array}$} & & \\
\hline $\begin{array}{l}\text { Rodzaj użytych odczynni- } \\
\text { ków }\end{array}$ & & & \\
\hline Dobór mierników, kalibracja & $\begin{array}{l}\text { Przeprowadzenie pomia- } \\
\text { rów parametrów badania }\end{array}$ & & \\
\hline \multirow{2}{*}{$\begin{array}{l}\text { Dobór defektoskopu, spo- } \\
\text { sób magnesowania, czas } \\
\text { wprowadzania pola, war- } \\
\text { tość natężenia pola magne- } \\
\text { tycznego }\end{array}$} & Magnesowanie powierzchni & $\begin{array}{l}\mathrm{Na} \\
\mathrm{rod}\end{array}$ & $\begin{array}{l}\text { żenie prądu, } \\
\text { aj prądu }\end{array}$ \\
\hline & $\begin{array}{l}\text { Nanoszenie proszku/ } \\
\text { zawiesiny }\end{array}$ & llos & nanoszonego proszku \\
\hline $\begin{array}{l}\text { Wielkość wskazań, } \\
\text { odległość nieciągłości } \\
\text { od badanej powierzchni }\end{array}$ & Oględziny & \multirow{2}{*}{\multicolumn{2}{|c|}{ Kwalifikacja obiektu }} \\
\hline \multirow[t]{3}{*}{$\begin{array}{l}\text { Zdolność widzenia operato- } \\
\text { ra badania, interpretacja }\end{array}$} & Ocena & & \\
\hline & $\begin{array}{l}\text { Dokumentacja } \\
\text { wyników }\end{array}$ & & \\
\hline & $\begin{array}{l}\text { Demagnetyzacja końcowa, } \\
\text { czyszczenie }\end{array}$ & & \\
\hline
\end{tabular}

Rys. 7. Diagram blokowy procesu

Fig. 7. Block diagram of the process wykonywanie kolejnych doświadczeń, których przebieg określa testowana kombinacja czynników, pełniących rolę zmiennych niezależnych. Im większa liczba czynników poddanych badaniu i im więcej poziomów, które przyporządkowuje się poszczególnym czynnikom, tym więcej kombinacji należy sprawdzić.

Celem eksperymentu było określenie wpływu zmian wartości poszczególnych parametrów badania na czułość wybranej metody badawczej oraz ocenę ujawnionych wskazań.

Badaniu poddano płytę próbną wykonaną ze stali S355. W płycie tej nawiercono płaskodenne, nieprzelotowe otwory, usytuowane na różnych głębokościach od badanej powierzchni, będących wartościami granicznymi dla poszczególnych poziomów akceptacji, zmieniających się o określoną wartość. Otwory te pełnią funkcję zasymulowanych nieciągłości, które pozwolą na określenie czułości metody badania przy określonych parametrach.

Diagram blokowy procesu badań magnetycznoproszkowych przedstawiono na rysunku 7.

Po analizie procesu poszczególnym zmiennym niezależnym przyporządkowano wartości reprezentujące górną oraz dolną granicę zakresu badawczego. Czynniki procesu oraz przypisane im poziomy wartości przedstawiono w tablicy II.

Po wykonaniu badań według założonego planu i ocenie otrzymanych wyników (w podanych zakresach) należy dokonać analizy wniosków.

Spostrzeżenia i zależności najlepiej umieścić w tablicy przedstawionej poniżej, w celu określenia, który czynnik ma największy wpływ na zmienność wyników oraz na ocenę czułości wybranej metody badawczej (tabl. III).

Tak opracowany plan eksperymentu pozwala na określenie czynników, które powodują wystąpienie krytycznych cech eksperymentu, a co za tym idzie - zmianę badanych parametrów w taki sposób, aby otrzymane wyniki były wiarygodne i dostosowane do wybranej metody badawczej.

Opisany przykład obrazuje funkcjonowanie planu eksperymentu, a przede wszystkim zależności, jakie występują pomiędzy wszystkimi uwzględnionymi zmiennymi. Przeprowadzone badania będą kontynuowane.

Tablica II. Poziomy wartości przypisane wybranym czynnikom procesu

Table II. Levels of the factors attributed to the selected process

\begin{tabular}{|l|c|c|}
\hline \multicolumn{1}{|c|}{ Zmienne niezależne } & $\begin{array}{c}\text { Poziom } \\
\text { dolny }\end{array}$ & $\begin{array}{c}\text { Poziom } \\
\text { górny }\end{array}$ \\
\hline Wymiary badanego elementu, mm & 100 & 300 \\
\hline $\begin{array}{l}\text { Czas wprowadzania pola } \\
\text { magnetycznego, min }\end{array}$ & 0,5 & 2 \\
\hline $\begin{array}{l}\text { Wartość natężenia pola magnetycznego, } \\
\text { kA/m }\end{array}$ & 2 & 6 \\
\hline $\begin{array}{l}\text { Odległość nieciągłości od powierzchni ba- } \\
\text { danej, mm }\end{array}$ & 0,5 & 3 \\
\hline
\end{tabular}


Tablica III. Wyniki eksperymentu prezentującego założenia statystyki Placketta - Burmana

Table III. Results of experiment of Plackett - Burman statistical assumptions

\begin{tabular}{|c|c|c|c|c|c|c|c|}
\hline \multirow{3}{*}{$\begin{array}{c}\text { Proces } \\
\mathrm{nr}\end{array}$} & \multicolumn{4}{|c|}{ Czynniki poddane badaniu, $\mathrm{k}$} & \multicolumn{3}{|c|}{ Efekty (odpowiedzi procesu) } \\
\hline & \multirow{2}{*}{$\begin{array}{c}\text { grubość } \\
\text { elementu } \\
\mathrm{mm}\end{array}$} & \multirow{2}{*}{$\begin{array}{c}\text { czas } \\
\text { wprowadzania pola } \\
\text { magnetycznego, s }\end{array}$} & \multirow{2}{*}{$\begin{array}{l}\text { wartość na- } \\
\text { tężenia pola } \\
\text { magn., kA/m }\end{array}$} & \multirow{2}{*}{$\begin{array}{c}\text { odległość nieciągło- } \\
\text { ści od badanej po- } \\
\text { wierzchni, mm }\end{array}$} & \multicolumn{2}{|c|}{ Główne } & \multirow{2}{*}{$\begin{array}{c}\text { Pomocnicze } \\
\text { wyrazistość } \\
\text { wskazania }\end{array}$} \\
\hline & & & & & $\begin{array}{c}\text { długość } \\
\text { wskazania, mm }\end{array}$ & $\begin{array}{l}\text { głębokość zalegania } \\
\text { nieciągłości, mm }\end{array}$ & \\
\hline 1 & 8 & 30 & 2,65 & $0,5-2,5$ & 65 & 3,44 & + \\
\hline 2 & 8 & 30 & 3,83 & $0,5-2,5$ & 56,5 & 2,99 & + \\
\hline 3 & 7 & 30 & 2,85 & $0,5-2,5$ & 66,2 & 3,51 & + \\
\hline 4 & 6 & 30 & 2,44 & $0,5-2,5$ & 75,2 & 3,98 & + \\
\hline 5 & 5 & 30 & 2,30 & $0,5-2,5$ & 73 & 3,86 & + \\
\hline 6 & 4 & 30 & 2,54 & $0,5-2,5$ & 61 & 3,23 & + \\
\hline 7 & 3 & 30 & 6,09 & $0,5-2,5$ & 65 & 3,44 & + \\
\hline
\end{tabular}

\section{Podsumowanie}

Formułowanie decyzji o stanie technicznym badanych obiektów odbywa się na podstawie badań diagnostycznych, których procedury wypracowuje się podczas eksperymentów.

Na podstawie niniejszego opracowania można zauważyć, jak ważny jest plan etapów określonych podczas badań które zwiększa prawdopodobieństwo osiągnięcia zamierzonych celów.

\section{Literatura}

[1] Braszczyński J.: Podstawy badań eksperymentalnych. PWN, Warszawa 1992

[2] Mańczak K.: Technika planowania eksperymentu. WNT, Warszawa 1976.

[3] Korzyński M.: Metodyka eksperymentu. WNT, Warszawa 2006.

[4] Braszczyński J.: Teoria eksperymentu technologicznego. Część 1: Projektowanie, wykonanie i opis eksperymentu. Wydawnictwa Politechniki Częstochowskiej, Częstochowa 1989.

[5] Polański Z.: Planowanie doświadczeń w technice. PWN, Warszawa 1984.

\section{Wydarzenia}

\section{Zakończenie IV Edycji konkursu na „Najlepsze osiągniecie techniczne 2010 roku”}

W dniu 10 grudnia 2011 r. podczas posiedzenia Zarządu Głównego SIMP odbyło się uroczyste spotkanie kierownictwa Stowarzyszenia z laureatami IV edycji konkursu na „Najlepsze osiągniecie techniczne 2010 roku".

Tegoroczna edycja konkursu rozszerzona została o prace nadesłane $z$ instytutów naukowo-badawczych. Spośród prac zgłoszonych do konkursu, komisja konkursowa postanowiła przyznać:

- Pierwsze miejsce przyznano Przemysłowego Instytutu Maszyn Rolniczych z Poznania za wdrożenie pt.: „Kombajn do zbioru i czyszczenia warzyw z wymiennymi adapterami roboczymi” oraz Hucie Stalowa Wola za 2 prace pt.: „Spycharka gąsienicowa TD-14M” i „Koparko-ładowarka 9.50M".

- Drugie miejsce przyznano Instytutowi Spawalnictwa w Gliwicach za opracowanie pt.: „Innowacyjna technologia zgrzewania tarciowego obwodowego pokrywy z tuleją cylindra siłownika neumatycznego, stosowanego w systemach bezpieczeństwa" oraz Centrum Techniki Okrętowej w Gdańsku za wdrożenie pt. „Projekt, budowa i uruchomienie wielkogabarytowego stanowiska do badania dymoszczelności drzwi i żaluzji”,

- Trzecie miejsce przyznano Instytutowi Technicznemu Wojsk Lotniczych w Warszawie za wdrożenie „Syste- mu diagnostyki tribologicznej statków powietrznych lotnictwa Sił Zbrojnych RP zgodny ze standardami NATO i programem Joint Oil Analysis Program (JOAP)", Toruńskim Zakładom Urządzeń Okrętowych TOWIMOR za osiągniecie pt. „Zespół urządzeń cumowniczo-kotwicznych z napędem hydraulicznym typu C16H+PK81", wdrożone w Stoczni HYUNDAI - Korea oraz Zakładom Urządzeń Technicznych UNIMASZ w Olsztynie za wdrożenie pt. „Reaktory fermentacyjne: jedno selekcyjny A i wielo selekcyjny B" dla Centrum Badania Energii Odnawialnej Uniwersytetu Warmińsko-Mazurskiego.

Ponadto wyróżniono dyplomami uznania następujące firmy: Kopex - Famago ze Zgorzelca za wdrożenie „Obrotnika łańcuchowego - zmodernizowanego”, Fabrykę Armatur JAFAR z Jasła za aktywny udział w kolejnych edycjach konkursu i wdrożenie do produkcji nowych przepustnic, a także Plasticon Poland z Torunia za wcześniejsze, ważne dla gospodarki narodowej, nagrodzone w poprzednich edycjach konkursu prace oraz za wdrożenie do produkcji „Systemu planowania, organizacji oraz kontroli realizacji zleceń produkcyjnych w obszarze Spoolsów TWS".

Dyplomy i wyróżnienia wręczyli prezes SIMP Andrzej Ciszewski i przewodniczący komisji konkursowej Janusz Gradowski. 